\title{
Seedbed Ecology of Winterfat: Fruits Versus Threshed Seeds
}

\author{
D. TERRANCE BOOTH AND GERALD E. SCHUMAN
}

\begin{abstract}
This series of studies compare winterfat establishment from whole fruits and seed. The studies have demonstrated that the long hairs of the fruit function as 'anchors' which help the radicle of a germinant to penetrate and begin growth into the soil. Other factors associated with the fruit also aid plant establishment. These factors have to do with better positive geotropic response of the radicle and with seedling vigor as measured by radicle growth in the soil. For these reasons, seedling establishment is better when fruits are broadcast, rather than when threshed seed is broadcast or planted at a $0.64 \mathrm{~cm}$ depth. Soaking fruits in water at $0^{\circ} \mathrm{C}$ for 48 hours significantly improved germination rate and percentage. Recommendations are made for field planting winterfat.
\end{abstract}

The fruit of winterfat [Eurotia lanata (Pursh) Moq.; Ceratoides l. (Pursh) J.T. Howell] is a utricle enclosed by two paper like bracts which form a sac or compartment. Fine, silky, white, pilose, hairs $3.2-6.4 \mathrm{~mm}$ (1/8 to $1 / 4$ inch) in length are found on the exterior of the bracts, these usually forming four dense, spreading tufts. In addition to the long hairs, white, stellate pubescence densely cover the outer walls of the bracts, especially near the bract tips and the pericarp of the utricle. Removal of the pericarp exposes a horseshoe shaped embryo around a small dry globule of perisperm; these being covered by a naked, transparent testa. A winterfat "seed" usually refers to the testa and its contents. "Fruit," as used in this paper, refers to the utricle and its enclosing bracts. The word "propagule" will be used to refer to both fruits and seeds.

The hairy bracts around the utricle are recognized as an aid to dispersal by wind (Hilton 1941, Stevens et al. 1977). Stevens et al. (1977) mention the importance of the bracts in protecting the seed and reducing precocious germination, therefore, they recommend planting fruits. The use of threshed seed is recommended by Springfield (1970), who compared emergence and survival of winterfat seedlings from seeds and fruits at 4 planting depths and reported greatest success with threshed seeds from a surface planting; the threshed seed establishing twice as many seedlings as the fruits.

Hilton (1941) investigated the effects of bracts and pericarp on germinability of winterfat. He reported a $10.5 \%$ reduction in germination when seeds were soaked in a decoction obtained from soaking whole fruits in distilled water. He also studied the physical restraint placed upon the embryo by the presence of the bracts, but found no effect other than a brief delay in emergence. Strickler (1956) noted that if the pilose hairs of the bracts were not sufficiently imbedded in the soil, the bracts remained over the cotyledons preventing photosynthesis in the new seedling. He also observed higher seedling mortality of seedlings from seeds. Winterfat establishes most successfully from on or near the surface of the soil during times of high soil moisture (Hilton 1941, Strickler 1956, Statler 1965, Springfield 1968 and 1970, Woodmansee and Potter 1971).

\footnotetext{
Authors are range scientist and soil scientist, USDA Agricultural Research Service. 8408 Hildreth Road, Cheyenne, Wyo. 82001 , respectively.

This research is a contribution from the USDA Agricultural Research Service, in cooperation with the Wyoming Agricultural Experiment Station.

Manuscript received January, 1982.
}

We conducted a series of studies to investigate the seedbed ecology of winterfat fruits and threshed seed with the hope of clarifying the advantages and disadvantages of each type of propagule.

\section{General Methodology}

Propagules for all of the studies were of 1979 harvest of NM-333 supplied by USDA-SCS Las Lunas, N. Mex., Plant Materials Center, Wendel Oaks, manager.

\section{Imbibition and Drying}

An evaluation of the moisture retaining capability of the fruit as compared to the seed, was made by weighing 100 of both seeds and fruits ( 20 groups of 5 ). These groups were then soaked in distilled water at room temperature. At 2, 4,6, and 8 hours, the propagules were removed from the water, blotted dry and weighted, then returned to the water. A 24 hour weighing was also made and the propagules were then placed on absorbant paper exposed to air at room temperature $20^{\circ} \mathrm{C}\left(70^{\circ} \mathrm{F}\right)$ and $18 \%$ relative humidity and were weighed after $2,4,6$, and 24 hours of drying.

Seed weight gain from imbibing water leveled off at about 8 hours. Fruits, on the other hand, were still gaining weight at the end of 24 hours. This difference in imbibition probably accounts for the lower precocious germination of fruits mentioned by Stevens et al. (1977). After 24 hours of imbibition, fruits weighed about $21 / 2$ times the maximum weight of the threshed seeds, which is about the same ratio as the dry propagules [dry seed $=\mathbf{2 . 6}$ $\mathrm{mg}\left(9.2 \times 10^{-5} \mathrm{oz}\right.$. $)$; dry fruit $=6.0 \mathrm{mg}\left(2.1 \times 10^{-4} \mathrm{oz}\right.$. $\left.)\right]$. The bracts and pericarp of the fruit offer very little protection from dessication. In the first 2 hours of drying, the naked seed lost $98 \%$ of the maximum weight gained in soaking (Fig. 1) compared to a $73 \%$ loss for fruits. After 6 hours seeds had lost $112 \%$ and fruits had lost $100 \%$ of the weight gained.

\section{Radicle Penetration}

This study was conducted to determine if penetration of the soil surface by the radicle was enhanced when some of the hairs of the fruit were embedded in the soil, giving the radicle a restraint to push against.

Ten greenhouse flats were filled with a 1:1 mixture of a sandy loam soil and peat moss; except the surface $12.7 \mathrm{~mm}(1 / 2$ inch $)$ which was the soil without the peat moss. The soil surface in all flats was purposely puddled by heavy sprinkling to make it more difficult for the radicle of a surface germinating propagule to penetrate and become established. Each flat was divided into $\mathbf{3 0}$ divisions or seed spots, which were then randomly assigned to one of the following seeding treatments: (1) the seed was pressed into the soil surface; (2) the seed was pressed into the soil surface and held there by a small piece of plastic coated wire (pinned) or (3) the fruit was pressed into the soil surface and manipulated to assure that some of the long hairs were embedded in the moist soil. Seeds and fruits were dusted with Captan prior to planting. Two hundred propagules were used per treatment. Soil moisture in the flats at the time of planting was at or near field capacity. The flats were watered as needed, and a clear plastic sheet was suspended over 


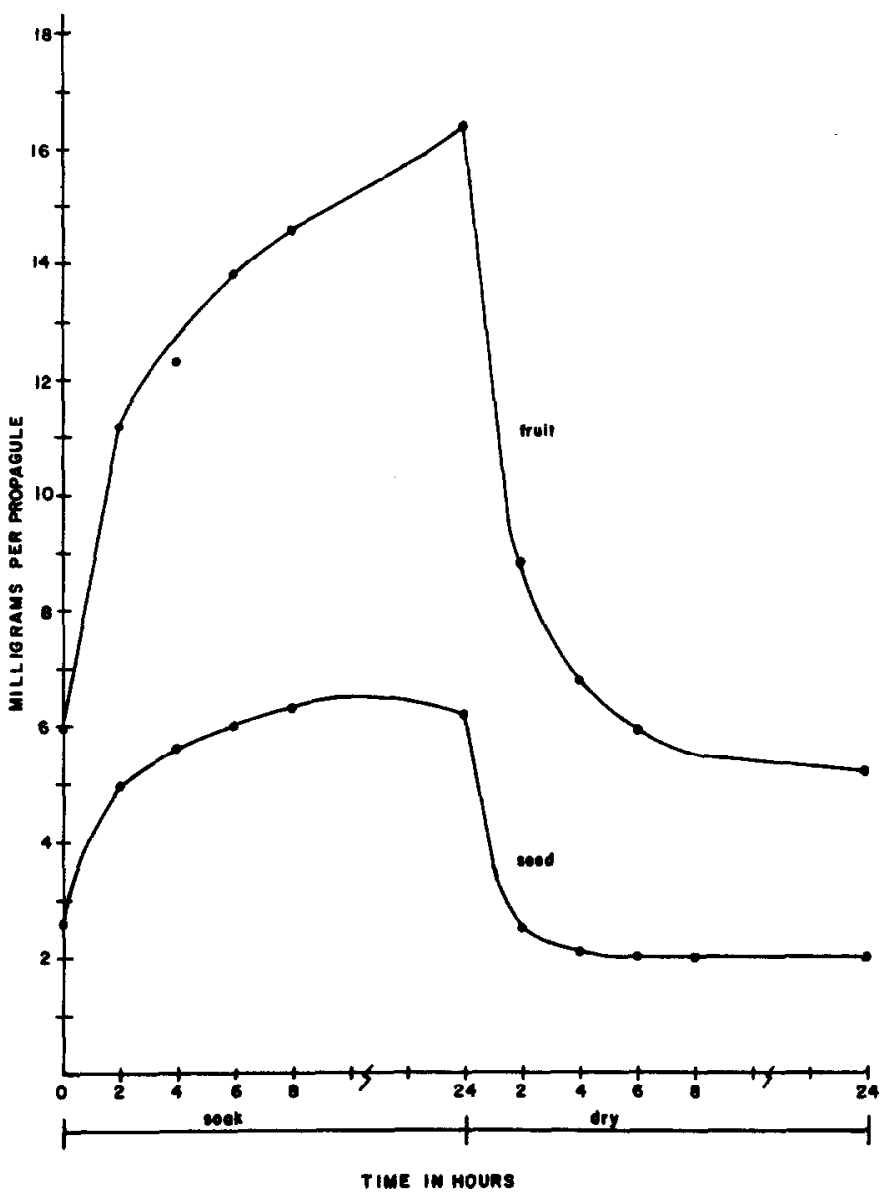

Fig. 1. Comparison of imbibition and subsequent drying of winterfat fruits and seeds at room conditions $\left(20^{\circ} \mathrm{C}\right.$ and $18 \%$ relative humidity).

them to maintain a desirable uniform moisture and humidity.

Fifteen days after planting, established plants were counted. A live seedling was considered established if the radicle had penetrated $10 \mathrm{~mm}$ or more into the soil. Greenhouse temperatures were between 21 to $27^{\circ} \mathrm{C}\left(70\right.$ to $\left.80^{\circ} \mathrm{F}\right)$ during the day and about 4.4 to $10^{\circ} \mathrm{C}\left(40\right.$ to $\left.50^{\circ} \mathrm{F}\right)$ at night.

Confidence limits ( 0.05 level) for the proportion of established seedlings to total propagules germinating, were calculated by using a binomial distribution (Steel and Torrie 1960).

Greater seedling establishment resulted from fruits $(69 \%)$ and from pinned seed (29\%) than from seeds (5\%), as is shown in Table 1. We can conclude that the anchoring effect of the pinned seeds and embedded fruit hairs significantly improved radicle penetration of the soil with a corollary improvement in the establishment of the seedlings. The mechanical advantage of the pinned seed or embedded hair is that of counterbalancing the upward force that the elongating radicle transmits to the propagule as it pushes into the soil. A significant difference between each of the 3 treatments indicates there are other factors associated with the fruit which aid the establishment of the young plant. From the imbibition and drying study we can assume that one of the additional factors is the extra weight of the whole fruit.

\section{Germination Test}

Because all fruits do not contain seeds, a germination test was made to compare viability of threshed seeds with that of fruits. The test was conducted in a germinator using petri-dishes and moist blotters at alternating temperatu res of $21^{\circ} \mathrm{C}$ for 16 hours and $4.4^{\circ} \mathrm{C}$ for 8 hours $\left(70\right.$ and $40^{\circ} \mathrm{F}$ ). The germination data show the maximum germination for seed was $97 \%$ after 5 days. Fruits germinated $49 \%$ after 5 days and $55 \%$ after 30 days. This information will be used to correct for this germination difference in the following studies.

\section{Field Study}

A field study was done in late June 1980 to test the applicability of the greenhouse results from the radicle penetration study. Number 10 cans with tops and bottoms removed, were placed in 3 rows of 99 cans each. Inside the cans 10 winterfat propagules were planted by (1) broadcasting seed onto the soil surface; (2) planting the seed $6.4 \mathrm{~mm}$ (1/4 inch) deep or (3) broadcasting fruits onto the soil surface. The purpose of the cans, was to prevent seeds and fruits from being moved by wind. Each planting method was repeated 33 times in each row. After planting, the area was sprinkle irrigated to apply $7.6 \mathrm{~cm}$ ( 3 inches) of water. Plots were then allowed to dry with no further watering for the duration of the study.

The sprinkling treatment was observed to cause fruit hairs to become embedded in the soil; however, no attempt was made to compare the number of fruits anchored with the number planted.

Twelve days after planting, 85 seedlings were growing from fruits broadcast on the soil surface, 26 from seed planted $6.4 \mathrm{~mm}$ (1/4 inch) deep, and 20 from seed broadcast on the soil surface.

Applying the results of the germination test to the results of the field study; we see that using fruits was about 7 times more successful than either of the planting methods using seed (Table 2).

\section{Geotropism Study}

It was observed that radicles of germinants from seed often did not show a positive geotropic response (Table 1). This study was conducted to determine if there is a difference in geotropic response of germinants from seeds and from fruits.

Fruits take longer to germinate than threshed seed (Hilton 1941, Springfield 1970). It was found that presoaking fruits at $0^{\circ} \mathrm{C}$ $\left(32^{\circ} \mathrm{F}\right)$ for 48 hours, allowed the fruits to germinate in the same 3day period required for germination of threshed seeds, thus allowing more accurate comparison of seed and fruit germinants for this study.

To obtain germinant populations of about 250 from each type of propagule, 520 fruits and 270 seeds were planted. The fruits were soaked in water for 48 hours at $0^{\circ} \mathrm{C}\left(32^{\circ} \mathrm{F}\right), \pm 2^{\circ}$, before planting. Greenhouse flats of a sandy loam soil were watered to field capac-

Table 1. Fate of winterfat propagules as a percent of number germinating.

\begin{tabular}{lccccc}
\hline \hline & $\begin{array}{c}\text { No geotropic } \\
\text { response }\end{array}$ & $\begin{array}{c}\text { Plants having a } \\
\text { radicle <10 mm }\end{array}$ & $\begin{array}{c}\text { Plants in which } \\
\text { radicle did not } \\
\text { penetrate }\end{array}$ & Establishment & $\begin{array}{c}\text { Confidence interval } \\
\text { (Z.05) }\end{array}$ \\
\hline $\begin{array}{c}\text { Seed } \\
\text { (94\% germination) }\end{array}$ & $9.5 \%$ & $1.1 \%$ & $84 \%$ & $5.3 \%$ & $2.1 \%$ to 8.71 \\
$\begin{array}{c}\text { Pinned seed } \\
(89 \% \text { germination) }\end{array}$ & $8.5 \%$ & $0.6 \%$ & $62 \%$ & $29 \%$ & $22.1 \%$ to 34.51 \\
$\begin{array}{c}\text { Fruit } \\
(48 \% \text { germination) }\end{array}$ & $2.0 \%$ & $8.3 \%$ & $21 \%$ & $69 \%$ & 59.7 to $77.9 \%$ \\
\hline
\end{tabular}

'Calculated using a mean germination of $92 \%$. 
Table 2. Winterfat estabilishment as a percent of propagules germinating in the field study.

\begin{tabular}{lcc}
\hline Treatment & $\begin{array}{c}\text { Percent } \\
\text { germination }\end{array}$ & $\begin{array}{c}\text { Percent } \\
\text { establishment }\end{array}$ \\
\hline Seed broadcast & 97 & 2.1 \\
Seed planted $6.4 \mathrm{~mm}(1 / 4 \mathrm{inch})$ & 97 & 2.7 \\
Fruits broadcast & 49 & 17.5 \\
\hline
\end{tabular}

ity and the propagules placed on the soil surface. No attempt was made to anchor the hairs of the fruits in the moist soil although some anchoring did occur naturally with subsequent watering. The flats were covered with clear plastic to maintain a high moisture level in the flats. After 3 days, counts were made of the number of propagules germinating, number of germinants in which the radicle grew up instead of down, and of the number of seedlings which became established. A seedling was considered established if the tip of the radicle had entered the soil.

Three hundred seventy-four fruits (72\%) germinated in the 3-day period. The calculated confidence intervals of this study and the above germination test indicate that the $17 \%$ (30-day test) imrovement following the 48-hour cold soak was a significant improvement. A similar 24-hour soak was not effective. The finding that the germination of winterfat fruits is increased by soaking in water for 48 hours at $0^{\circ} \mathrm{C}\left(32^{\circ} \mathrm{F}\right)$ is supported by observations (Strickler 1956) that cold treatment 1.1 to $\left.4.4^{\circ} \mathrm{C} \mathrm{(34} \mathrm{to} 40^{\circ} \mathrm{F}\right)$ for 1 week, followed by incubation between 17 to $23^{\circ} \mathrm{C}\left(62\right.$ to $\left.74^{\circ} \mathrm{F}\right)$ improved germination of both seeds and fruits.

From fruits, 105 seedlings established ( $28 \%$ of germination). Two hundred sixty-nine germinants did not establish; of these 57 did not show positive geotropism. Two hundred forty-six threshed seeds germinated $(91 \%)$ but only 16 established as seedlings (7\% of germination). Sixty seed germinants showed no geotropism.

The confidence intervals for the proportion of fruit germinants showing no geotropism (15\%-0.1160 to 0.1889 ); of seed germinants (24\%-0.1900 to 0.2978$)$. Therefore, it can be concluded that fruits have significantly fewer germinants which lack a positive geotropic response by the radicle.

Germinants from fruits which did not establish, but which did show positive geotropism totaled 212 or $57 \%$. This is significantly less establishment than occurred in the radicle penetration study (confidence intervals: radicle penetration study $=0.1536$ to 0.2665 ; geotropism study $=0.5166$ to 0.6170 ). Remembering that the pilose hairs were not anchored in this study, it again demonstrates the importance of the embedded hairs of the bracts to seedling establishment.

\section{Seedling Vigor Study}

Seedling vigor was measured by radicle elongation of winterfat seedlings from fruits and seed.

Four root observation boxes, $104 \times 61 \times 2.5 \mathrm{~cm}(41 \times 24 \times 1$ inch) were filled with $45 \mathrm{~cm}$ (18 inch) of perlite and a $15-\mathrm{cm}(6 \mathrm{inch})$ top layer of sandy loam soil. The plexiglass front was covered with opaque paper. The boxes were placed in a controlled environment room where the temperature was $21^{\circ} \mathrm{C}\left(70^{\circ} \mathrm{F}\right)$ for 16 hours with light, and $4.4^{\circ} \mathrm{C}\left(40^{\circ} \mathrm{F}\right)$ for 8 hours without light. The boxes were inclined at $25^{\circ}$ to encourage roots to grow along the soil-plexiglass interface.

One hundred threshed seed and 100 whole fruits of winterfat were soaked for 48 hours at $0^{\circ} \mathrm{C} \pm 2^{\circ}\left(32^{\circ} \mathrm{F}\right)$. After soaking, the propagules were randomly placed on the moist soil surface, 25 of each to a box, and covered with wet paper towel. Special effort was made to insure good contact between the towel, seed or fruit, and the soil.

After 5 days the paper towel was removed, as were nongerminating propagules and germinants which did not have a radicle firmly established in the soil. Note was made of germinants which appeared to lack geotropism.
The opaque paper was removed from the boxes after 15 days and the length of the radicle measured from the soil surface. A leastsquares analysis of variance was used to test differences in the mean radicle lengths.

From the 100 threshed seeds in this study, 26 plants established and had an average radicle length of $28 \mathrm{~mm}$ (1.1 inch) after 15 days. Eight germinants did not show geotropism. The 100 fruits produced 74 established plants which had an average radicle length of $46 \mathrm{~mm}$ (1.8 inch). This difference is highly significant and indicates the superior vigor of seedlings established from fruits. Two fruit germinants did not show geotropism. Voorhees (1976) found that rates of root growth under the conditions similar to those described in the vigor study should not be generally assumed to extrapolate to root growth under field conditions.

\section{Summary and Recommendations}

These studies have demonstrated 3 important ways the whole fruit aids seedling establishment. First, the hairs of the bracts become embedded in the soil surface and restrain the fruit, the reby improving radical penetration of the soil. Second, threshed seeds have been shown to have a significant population (up to $24 \%$ ) of germinants which lack a positive geotropic response by the radicle. (From a separate study conducted subsequent to submission of this paper; we determined that the geotropic deficiency found in threshed seed is due to damage to the embryo rootcap during threshing. Details of the study will be reported elsewhere.) Third, a comparison of seedling vigor, as measured by radicle elongation of seedlings established from fruits and from seed, found radicle growth from fruits to be almost twice that of seedlings from seeds.

The key to successful plantings of a shrub is an understanding of the way the propagule interacts with its environment, and in using this understanding to produce the desired result. On the bases of the above results, the literatue reviewed and experience, the following recommendations can be made for improving the planting success of winterfat.

1. Use good, large, healthy appearing fruits (and not threshed seed) which have been allowed to afterripen at room temperature for 2 months before storage in a cold $\left(0\right.$ to $4^{\circ} \mathrm{C}-32$ to $\left.39^{\circ} \mathrm{F}\right) \mathrm{dry}$ environment.

2. Broadcast the whole fruits. The seedbed must be rough, providing numerous places for the fruits to lodge-otherwise most of the fruits will be blown off the area being planted. In some instances a broadcast seeder, such as a Brillion Seeder ${ }^{1}$, may effectively plant winterfat fruits at the required shallow $(6.4 \mathrm{~mm}-$ $1 / 4$ inch or less) depth.

3. In planting in an area of winter precipitation, plant as late in the fall as possible. A snow cover soon after planting will further reduce the amount of fruit lost due to the wind.

4. If working in an area which is likely to have a dry surface soil during the winter-plant in the spring when the probability is greatest of having extended periods of soil moisture between field capacity and saturation. Also keep in mind that the larger the young plants are when hot weather 20 to $27^{\circ} \mathrm{C}(70$ to $80 \mathrm{~F})$ arrives, the better the survival.

5. A spring planting of fruits soaked for 48 hours at $0^{\circ} \mathrm{C}\left(32^{\circ} \mathrm{F}\right)$ followed by hand planting in moist soil, can be recommended as a technique to enhance establishment of a few plants which may serve as sources of fruits for later natural revegetation or as special area plantings. The soaked fruits must not dry before germination occurs.

\section{Literature Cited}

Hilton, James, W. 1941. The effects of certain microecological factors on the germinability and the early development of Eurotia lanata. Northwest Sci. 15:86-92.

Use of trade name is for information only and does not imply endorsement of this product over similar equipment. 
Springfield, H.W. 1968. Germination of winterfat seeds under different moisture stresses and temperatures. J. Range Manage. 21:314-316.

Springfield, H.W. 1970. Emergence and survival of winterfat seedlings from four planting depths. USDA-FS. Rocky Mountain Forest and Range Exp. Sta. Res. Note RM-162.

Statler, Glen, D. 1965. Eurotia lanata establishment trials. M.S. Thesis, Univ. Wyoming, Laramie.

Steel, Robert G.D., and James H. Torrie. 1960. Principles and procedures of statistics. McGraw-Hill. New York.
Stevens, Richard, B.C. Giunta, K.R. Jorgensen, and A.O. Plummer. 197 Winterfat (Ceratoides lanata). Pub. No. 77-2, Utah State Division. Wild life Resources.

Strickler, G.S.S. 1956. Factors affecting the growth of whitesage [Eurot: lanata (Pursh.) Moq.]. M.S., Univ. Nevada, Reno.

Voorhees, W.B. 1976. Root elongation along a soil-plastic container inte face. Agron. J. 68:143.

Woodmansee, R.G., and L.D. Potter. 1971. Natural reproduction , winterfat (Eurotia lanata). New Mexico J. Range Manage. 24:24-30. 